\title{
Cows with paratuberculosis (Johne's disease) alter their lying behavior around peak lactation
}

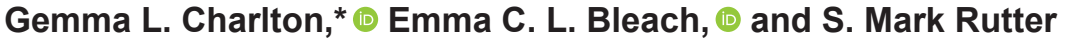 \\ Animal Production, Welfare and Veterinary Sciences, Harper Adams University, Shropshire, United Kingdom TF10 8NB
}

\section{ABSTRACT}

Paratuberculosis or Johne's disease (JD) is a fatal chronic enteritis that causes detrimental effects on production and health and significantly reduces the welfare of cattle. Control of JD is highly desirable, but single milk ELISA testing may not be sensitive enough to identify all affected animals, particularly in the early stages of the disease. The objective of this study was to compare the activity of JD-positive (JD5) to JD-negative (JD0) cows from calving until wk 20 of lactation. The study was conducted at Harper Adams University, United Kingdom, using 42 multiparous [3.1 \pm 0.22 (mean \pm standard error of the mean); range: 2-7 lactations] Holstein Friesian cows, fitted with an IceQube accelerometer (IceRobotics Ltd., Edinburgh, UK) on the back left leg. The sensors recorded data on lying and standing time, steps, and motion index with a granularity of 15 min. In addition, start and stop times for lying bouts, and exact lying bout durations were recorded, which permits calculation of the number of lying bouts. Every 3 mo the cows were milk sampled and subsequently tested for JD using an ELISA. Cows in the infection group JD0 were classed as JD negative and cows in the infection group JD5 were classed as JD positive. Johne's-positive cows [JD5; $\mathrm{n}=21$ (repeat ELISA positive)] were matched to negative cows [JD0; $\mathrm{n}=21$ (repeat ELISA negative)] based on lactation number and age. Around peak lactation we found differences in lying behavior. The JD5 cows spend less time lying/d during wk 7 to 11 of lactation. The largest difference observed was around wk 8 of lactation, with JD5 cows spending, on average, $2 \mathrm{~h} / \mathrm{d}$ less time lying down than JD0 cows $(9.3 \pm 0.33$ vs. $11.3 \pm 0.61 \mathrm{~h} / \mathrm{d}$, respectively). The JD5 cows also had fewer lying bouts per day from wk 7 to 15 of lactation (excluding wk 13), and during wk 11 and 12 average lying bout duration was longer for JD5 cows compared with JD0 cows. No differences were observed in steps per day, milk yield,

Received April 24, 2019.

Accepted August 25, 2019.

*Corresponding author: gcharlton@harper-adams.ac.uk
BCS, and mobility score between JD5 and JD0 cows from calving to wk 20 of lactation. As far as we are aware, this is the first study to show changes in activity of JD-positive cows. The results show that activity data from leg-mounted accelerometers has the potential to help identify JD-positive cows, although more research is required.

Key words: Johne's disease, paratuberculosis, dairy cattle, lying behavior, Mycobacterium avium ssp. paratuberculosis

\section{INTRODUCTION}

Johne's disease (JD), also known as paratuberculosis is a fatal chronic enteritis of ruminants caused by Mycobacterium avium ssp. paratuberculosis (MAP; Fecteau, 2018). The main route of transmission is the fecal-oral route (Garcia and Shalloo, 2015) and it is during the first 6 mo of life that cattle are most likely to become infected (Cocito et al., 1994). The first stage of the disease is silent with no clinical signs shown, and although MAP may be shed in the feces, the levels are not detectable using current methods (Fecteau, 2018). As the disease progresses, infected animals still appear healthy and do not show clinical signs of JD, but detectable levels of MAP are shed in the feces that can contaminate the environment and possibly infect other animals (Weber et al., 2010). The rate of disease progression varies and the clinical stage of the disease which includes a gradual loss of condition and a change in the consistency of feces may begin between 2 and $6 \mathrm{yr}$ of age, although it can range from 4 mo to $15 \mathrm{yr}$ (Henderson et al., 2001). In the final, terminal stage of the disease cattle become weak, lethargic, and have chronic, profuse diarrhea with a rapid loss of body condition (Stabel, 1998).

Johne's disease is a worldwide problem, with no country proving they are free from MAP (Nielsen and Toft, 2009). In North America, the United Kingdom, and Europe, JD is considered endemic, with prevalence levels thought to be greater than 50\% (USDA, 2008; Nielsen and Toft, 2009; Woodbine et al., 2009). Although Ott et al. (1999) estimates the cost of JD to the 
US dairy industry as $\$ 200$ to $\$ 250$ million annually, calculating economic losses associated with JD is difficult. Infected animals may have an increased risk of other diseases, such as mastitis (Pritchard et al., 2017; Rossi et al., 2017), and milk production is reduced (Martins et al., 2018), so many infected animals may be culled before the clinical stages of JD and therefore misclassified (Caldow et al., 2001).

Serum and milk ELISA tests are commonly used to identify cattle infected with JD (Garcia and Shalloo, 2015), but diagnosing and controlling JD is difficult due to inaccurate tests, a long incubation period, and a lack of clinical signs until the advanced stages of the disease (Nielsen and Toft, 2008; Fecteau, 2018). Henderson et al. (2001) states that generally, during the early stages of the clinical phase of the disease, infected cows show no change to appetite, but drinking may increase to compensate for the fluid loss from diarrhea. During the preclinical stage of the disease, the behavior of JD-positive cows is unknown. Monitoring animal behavior can be useful to detect poor health, as activity levels and lying time can change in response to disease. For example, lame cows spent $2.1 \mathrm{~h} / \mathrm{d}$ longer lying than non-lame cows (Blackie et al., 2011) and cows with mastitis had reduced lying times, a higher number of daily lying bouts, and took more steps than healthy cows (Fogsgaard et al., 2015). To our knowledge no study has investigated behavioral changes as a result of JD during the preclinical stages of the disease. Therefore, the objective of this study was to compare the activity of JD-negative cows (JD0) to JD-positive cows (JD5) in a preclinical state of JD from calving to wk 20 of lactation.

\section{MATERIALS AND METHODS}

\section{Animals and Management}

The study was carried out at Harper Adams University, United Kingdom, from May 2015 to May 2017 using 42 multiparous $[3.1 \pm 0.22$ (mean $\pm \mathrm{SEM})$; range: 2-7 lactations] Holstein Friesian cows from 0 to $20 \mathrm{wk}$ of lactation. On the day of calving, cows were moved to 1 of $2(5.0 \mathrm{~m} \times 13.0 \mathrm{~m})$ calving pens. Toward the back of each pen was a $5.0 \mathrm{~m} \times 8.8 \mathrm{~m}$ area with deep bedded straw and toward the front was a $5.0 \mathrm{~m} \times 4.2$ $\mathrm{m}$ concrete feed passage where the cows could access TMR. Fresh TMR (maize silage, wheat straw, grass silage, spey syrup, minerals, and limestone) was provided daily at approximately $0600 \mathrm{~h}$ and was pushed up a minimum of 5 times/d. Fresh drinking water was available ad libitum. Each day fresh bedding was added and the feed passage was scraped 5 times/d using an automatic scraper.
From $1 \mathrm{~d}$ postcalving until approximately $3 \mathrm{wk}$ postcalving, cows were housed in a straw yard, with approximately 45 cows in the straw yard at any one time. The yard was approximately $52.0 \mathrm{~m} \times 13.0 \mathrm{~m}$ with deep bedded straw $(52.0 \mathrm{~m} \times 8.8 \mathrm{~m})$ toward the back of the yard and a concrete feed passage $(52.0 \mathrm{~m} \times 4.2$ $\mathrm{m})$ toward the front, where the cows could access TMR. Fresh TMR (maize silage, lucerne, wheat straw, spey syrup, sweet starch, soya hulls, minerals, limestone, and urea) was provided daily at approximately $0600 \mathrm{~h}$ and was pushed up a minimum of 5 times/d. Fresh straw bedding was added daily and an automatic scraper was used to clean the feed passage 5 times/d. The cows had ad libitum access to drinking water. From approximately 3 wk postcalving the cows were moved to be housed indoors with $1.3 \mathrm{~m} \times 2.5 \mathrm{~m}$ freestalls with 3 -cmthick rubber mattresses. There were approximately 105 freestalls per 100 cows. Freestalls were bedded twice weekly with sawdust and the passageways were scraped 5 times/d using automatic scrapers. Fresh TMR was provided daily at approximately $0600 \mathrm{~h}$ and was pushed up a minimum of 5 times/d and the cows had ad libitum access to drinking water. Twice a day from 0500 and $1500 \mathrm{~h}$ the cows were milked in a 40-point internal rotary parlor. Incidences of mastitis were recorded and treated as they arose. Over the course of the study, 2 JD0 cows suffered moderate mastitis and one JD0 and 2 JD5 cows suffered severe mastitis. All 5 cows were treated and made a full recovery. Ethical approval for the study was given by Harper Adams University Research Ethics Committee.

\section{Measurements}

Behavior Recordings. All of the cows had an IceQube accelerometer-based sensor (IceRobotics Ltd., Edinburgh, UK) attached to the back left leg for a minimum of $4 \mathrm{wk}$ before the start of the study, using a Velcro hook and loop strap. IceQubes have been previously validated (Borchers et al., 2016) and provide data on lying and standing time, steps, and motion index with the granularity of $15 \mathrm{~min}$. In addition, start and stop times for lying bouts, and exact lying bout duration, which permits calculation of number of lying bouts, were also provided. Activity data were stored within the IceQube and automatically downloaded wirelessly to the CowAlert system (IceRobotics Ltd.) each time the cows walked past the reader at the entrance to the milking parlor.

Milk Sampling and Analysis, BCS, and Mobility Scoring. Milk yields were recorded automatically for each individual cow twice/d by a computerized recording system (Westfalia Surge, Milton Keynes, UK). At approximately 1000 h, every 2 wk, throughout 
the study the cows were body condition scored using the Elanco scoring system of 1 to 5 in increments of 0.25 (Elanco Animal Health, 1996). Weekly, from approximately $1520 \mathrm{~h}$ the cows were mobility scored as they left the milking parlor and walked along a concrete raceway back to the home pen. A score of 1 (smooth and fluid movement) to 5 (ability to move is severely restricted and must be vigorously encouraged to move) was given to each cow, according to Flower and Weary (2006). Throughout the study, BCS and mobility scoring were carried out by the same experienced person.

Every 3 mo the cows were milk sampled and subsequently tested for JD through National Milk Records (NMR) via the commercial milk ELISA Idexx Mycobacterium paratuberculosis Screening Antibody Test (Idexx Laboratories Inc., Westbrook, ME; Bartlett and Pearse, 2012). Sensitivity of the test is estimated at 40 to $80 \%$ and specificity $>99 \%$ (NMR, undated). Johne's disease classifications and definitions are shown in Table 1 . Cows classed as JD-negative (JD0; $\mathrm{n}=21$ ) had a minimum of 2 consecutive negative ELISA results and JD-positive cows (JD5; $\mathrm{n}=21$ ) had a minimum of 2 positive ELISA results. The JD5 cows were all in the subclinical stage of the disease with no obvious clinical symptoms. The JD5 and JD0 cows were matched based on lactation number and age.

\section{Statistical Analysis}

The dependent variables daily lying duration, lying bout frequency, average lying bout duration, step count, milk yield, BCS, and mobility were analyzed by repeated measures ANOVA to compare the 2 treatment groups (JD0 and JD5) each week from calving to wk 20 of lactation and included the group $\times$ time interaction. This model used a Greenhouse-Geisser correction. Model residuals were examined to ensure normality and homogeneity of variances. One-way ANOVA was used to compare average activity within week (lying duration, lying bout frequency, average lying bout duration, and step count), milk yield, and mobility of JD5 and JD0 cows and fortnightly BCS. All statistical analysis was conducted using Genstat 18th edition (VSN International Ltd., Hemel Hempstead, UK) and is presented as means with the standard error of the mean; $P<0.05$ was used as the significance threshold and a trend was considered when $P<0.10$.

\section{RESULTS}

\section{Behavior Data}

From calving to wk 20 of lactation, JD5 cows showed a tendency to spend, on average, $1 \mathrm{~h} / \mathrm{d}$ less lying down compared with JD0 cows $\left(F_{1,40}=3.42, P=0.072 ; 10.2\right.$ \pm 0.17 vs. $11.2 \pm 0.09 \mathrm{~h} / \mathrm{d}$, respectively) and lying time changed over time $\left(F_{20.772}=8.39, P<0.001\right)$. Daily lying times were approximately $12 \mathrm{~h} / \mathrm{d}$ at calving in both groups but decreased from calving to wk 5 of lactation. Subsequently, lying times increased to periparturient levels by wk 8 for JD0 cows, whereas those of JD5 cow did not reach periparturient levels until wk 16. No $\mathrm{JD} \times$ time interaction $\left(F_{20,772}=1.65, P=0.134\right)$ was observed. One-way ANOVA revealed that during wk 7 to 11 of lactation, JD5 cows spent less time lying down (Figure 1; $P<0.05$ ). The difference was greatest at around wk 8 of lactation, with JD5 cows spending 2 $\mathrm{h} / \mathrm{d}$ less lying down compared with JD0 cows. There was no difference in lying time between JD5 and JD0 cows from calving to wk 6 and from wk 12 to 20 of lactation. For JD5 cows, mean lying time/d over $20 \mathrm{wk}$ (from calving to wk 20 of lactation) ranged from 7.5 to $12.4 \mathrm{~h} / \mathrm{d}$ and for JD0 cows from 6.1 to $15.8 \mathrm{~h} / \mathrm{d}$.

Figure 2 shows the mean daily lying bout frequency. Mean lying bout frequency from calving to wk 20 of lactation was lower for JD5 compared with JD0 cows $\left(F_{1,40}=5.93, P=0.019 ; 10.4 \pm 0.25\right.$ vs. $12.2 \pm 0.17$, respectively). A difference was also present in daily lying bout frequency over time $\left(F_{20,771}=5.93, P<0.001\right)$, but no interaction between JD $\times$ time $\left(F_{20,771}=1.58, P\right.$ $=0.157$ ). During wk 7 to 12 , wk 14 to 15 , and wk 19 of lactation, JD5 cows had fewer lying bouts/d compared with JD0 cows $(P<0.05)$. During wk 11 of lactation JD5 cows had, on average, 3.6 fewer lying bouts/d compared with JD0 cows $(P=0.001 ; 9.2 \pm 0.50$ vs. 12.8 \pm 0.92 , respectively). There was no difference in mean lying bout duration between JD5 and JD0 cows from calving to wk 20 of lactation $\left(F_{1,40}=2.02, P=0.163\right.$;

Table 1. Classification and definition of Johne's disease (JD) infection groups from National Milk Records, United Kingdom

\begin{tabular}{llll}
\hline Risk level & Classification & JD infection group & Definition \\
\hline Low & Green & JD0 & Repeat ELISA negative (minimum 2 tests) \\
Low & Green & JD1 & ELISA negative but only 1 test \\
Low & Green & JD2 & ELISA negative but positive within 3 previous tests \\
High & Amber & JD4 & ELISA negative but previous test positive \\
High & Amber & JD5 & Last ELISA positive, all previous tests negative \\
High & Red & & Repeat ELISA positive (minimum 2 tests) \\
\hline
\end{tabular}




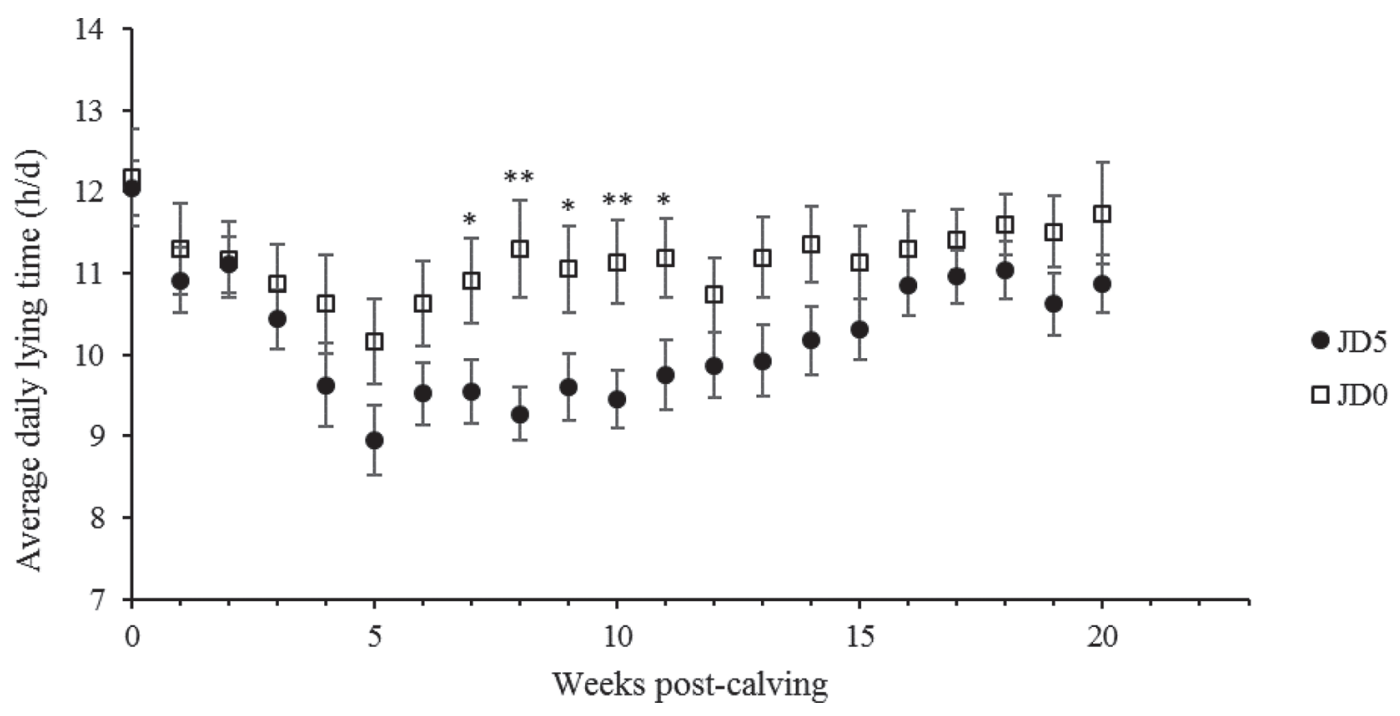

Figure 1. Mean ( \pm SEM) daily lying time $(\mathrm{h} / \mathrm{d})$ of Johne's disease (JD)-positive [JD5; $\mathrm{n}=21$ (repeat ELISA positive)] and JD-negative $\left[\mathrm{JD} 0 ; \mathrm{n}=21\right.$ (repeat ELISA negative)] Holstein Friesian dairy cows from calving to wk 20 of lactation $\left(\mathrm{JD}, F_{1,40}=3.42, P=0.072 ;\right.$ time, $F_{20,772}$ $=8.39, P<0.001 ; \mathrm{JD} \times$ time, $\left.F_{20,772}=1.65, P=0.134\right) .{ }^{*} * P<0.01 ; * P<0.05$.

$61.6 \pm 1.11$ vs. $57.6 \pm 0.84 \mathrm{~min} / \mathrm{d}$, respectively) and no $\mathrm{JD} \times$ time interaction $\left(F_{20,770}=0.93, P=0.469\right)$. However, mean lying bout duration changed over time from calving to wk $20\left(F_{20,770}=6.55, P<0.001\right)$. Figure 3 shows that during wk 11 and 12, JD5 cows spent, on average, 10.4 and $11.5 \mathrm{~min}$ longer lying/bout compared with JD0 cows $(P<0.05$; Figure 3$)$. Step counts of JD5 and JD0 cows were similar $\left(F_{1,40}=0.18, P=0.676\right.$; $1,489.4 \pm 59.83$ vs. $1,414.0 \pm 48.47$, respectively) from calving to wk 20 of lactation. There was no difference in average daily step count each week $(P>0.05$; Figure 4 ), although step count of the 2 groups did change over time $\left(F_{20,772}=10.72, P<0.001\right)$. There was no JD $\times$ time interaction $\left(F_{20,772}=0.65, P=0.656\right)$.

\section{Milk Sampling and Analysis, BCS, and Mobility Scoring}

Mean milk yield throughout the study was $39.8( \pm 0.54$ $\mathrm{kg} / \mathrm{d})$, mean BCS was $2.8( \pm 0.03)$, and mean mobility

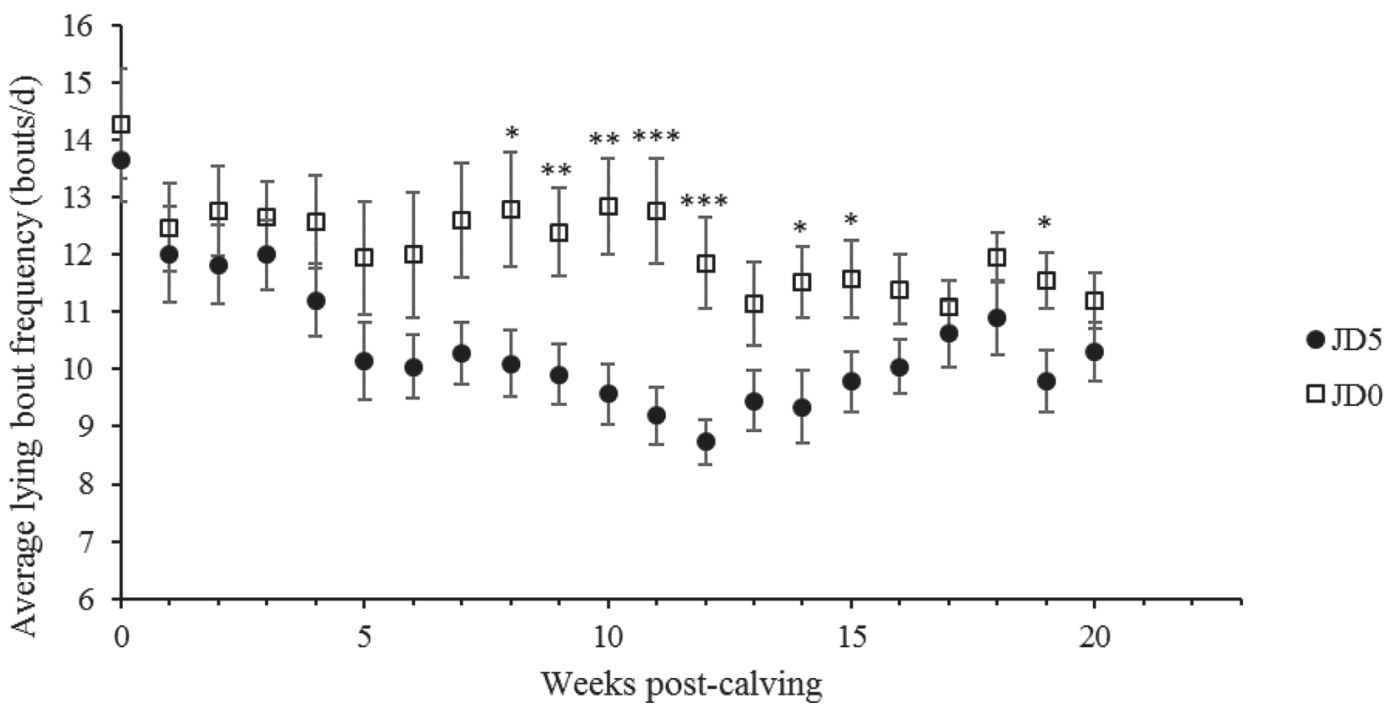

Figure 2. Mean ( \pm SEM) daily lying bout frequency (bouts/d) of Johne's disease (JD)-positive [JD5; $\mathrm{n}=21$ (repeat ELISA positive)] and JD-negative [JD0; $\mathrm{n}=21$ (repeat ELISA negative)] Holstein Friesian dairy cows from calving to wk 20 of lactation $\left(\mathrm{JD}, F_{1,40}=5.93, P=0.019\right.$; time, $F_{20.771}=5.93, P<0.001 ; \mathrm{JD} \times$ time, $\left.F_{20.771}=1.58, P=0.157\right)$. ${ }^{* * *} P<0.001 ;{ }^{* *} P<0.01 ; * P<0.05$. 
score was $2.2( \pm 0.05)$. There were no differences in milk yield $\left(F_{1.40}=0.80, P=0.377\right), \mathrm{BCS}\left(F_{1.40}=0.36, P\right.$ $=0.553)$, or mobility score $\left(F_{1,39}=1.67, P=0.205\right)$ between JD5 and JD0 cows and from calving to wk 20 of lactation milk yield (Figure 5), BCS (Figure 6), and mobility score (Figure 7) remained similar between the 2 groups $(P>0.05)$. Milk yield $\left(F_{19,709}=18.93, P<\right.$ $0.001)$ and $\operatorname{BCS}\left(F_{10,393}=13.40, P<0.001\right)$ did change over time and there was a tendency for mobility score to change over time $\left(F_{20,746}=1.90, P=0.055\right)$. There was no interaction between JD $\times$ milk yield $\left(F_{19,709}=\right.$ $0.64, P=0.543), \mathrm{JD} \times \mathrm{BCS}\left(F_{10,393}=0.68, P=0.638\right)$, or JD $\times$ mobility score $\left(F_{20,746}=0.79, P=0.623\right)$.

\section{DISCUSSION}

The results of the current study show promise that changes in lying behavior around peak lactation may be a valuable tool to help detect cows with JD. Around peak lactation, JD5 cows spent up to $2 \mathrm{~h} / \mathrm{d}$ less time lying and had fewer lying bouts compared with JD0 cows. During wk 11 and 12 of lactation, JD5 cows also had a longer lying bout duration, yet no clinical signs of JD were apparent in the cows. Although to the authors' knowledge, no other studies have investigated the effect of JD on dairy cattle behavior, research has shown that other diseases and health disorders can cause a change in lying behavior and monitoring animal behavior can be useful to assist in detecting health problems in dairy cattle (Mattachini et al., 2013). Blackie et al. (2011) found that lame cows spent more than $2 \mathrm{~h} / \mathrm{d}$ longer lying down compared with non-lame cows. Similar results were reported by Ito et al. (2010) with severely lame cows increasing their lying time by $1.6 \mathrm{~h} / \mathrm{d}$ and increasing lying bout duration by $15 \mathrm{~min} /$ bout compared with cows that were not severely lame. Reduced lying and an increase in the daily number of lying bouts has been found for cows with mastitis compared with control cows (Fogsgaard et al., 2015) and cows that were later diagnosed with ketosis also reduced their lying time (Itle et al., 2015).

In the current study, there was no difference in lying behavior between JD5 and JD0 cows around calving and activity before calving was not recorded. However, other studies have found lying behavior changes before calving in response to other health disorders. Itle et al. (2015) found that cows with clinical ketosis spend 2.4 $\mathrm{h} / \mathrm{d}$ less time lying in the week before calving and 4.5 $\mathrm{h} / \mathrm{d}$ less time lying on the day of calving, compared with nonketotic cows. Similarly, Neave et al. (2018) found that cows later diagnosed with metritis spent around $40 \mathrm{~min}$ less time lying/d and had fewer lying bouts in the 2 wk before calving compared with healthy cows. This research indicated that lying behavior may change at different stages of a health disorder (Neave et al., 2018) and possibly different stages of the lactation cycle. These findings suggest that future research examining the behavioral changes of cows with JD should focus on other critical stages such as before calving and around dry-off.

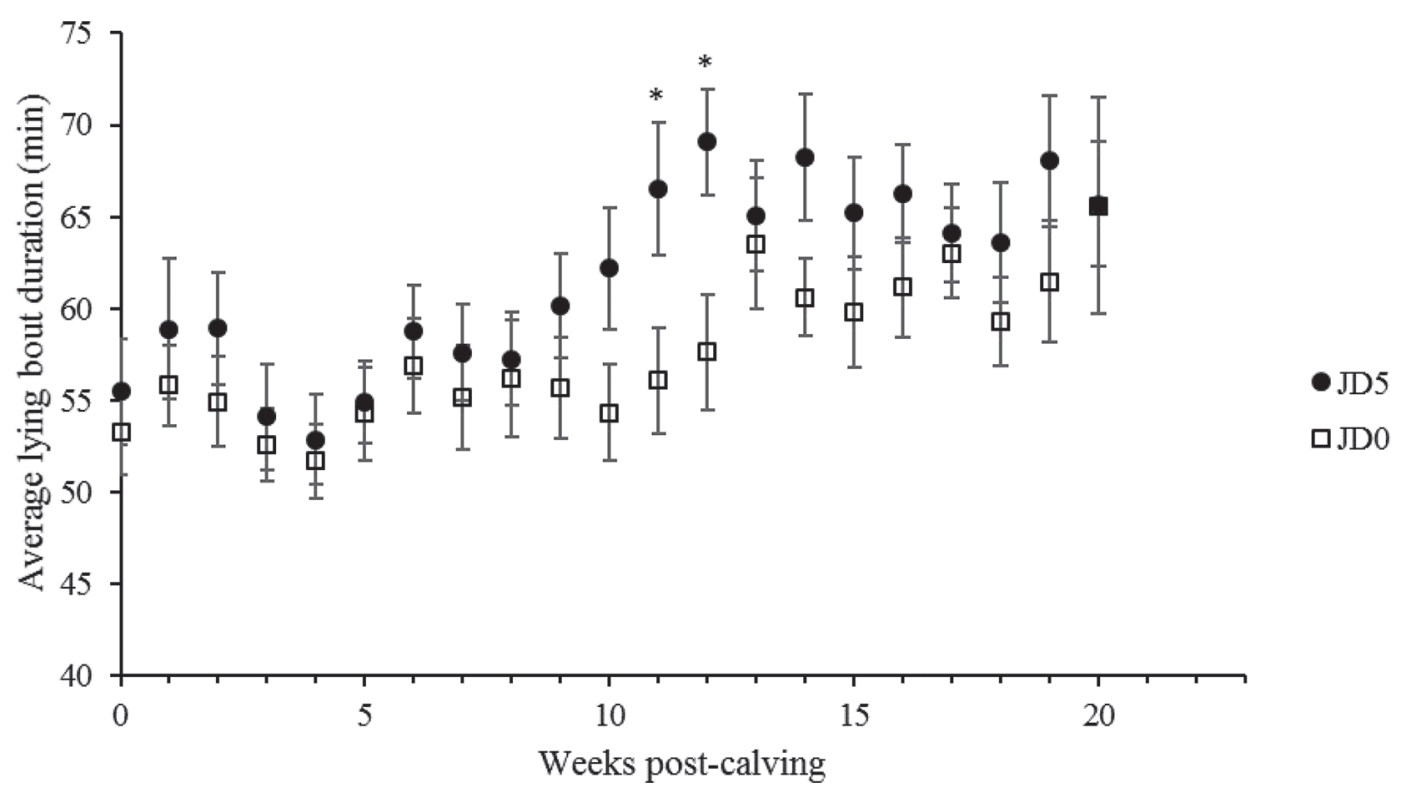

Figure 3. Mean ( \pm SEM) lying bout duration (min) of Johne's disease (JD)-positive [JD5; $\mathrm{n}=21$ (repeat ELISA positive)] and JD-negative $\left[\mathrm{JD} 0 ; \mathrm{n}=21\right.$ (repeat ELISA negative)] Holstein Friesian dairy cows from calving to wk 20 of lactation $\left(\mathrm{JD}, F_{1,40}=2.02, P=0.163 ;\right.$ time, $F_{20,770}$ $=6.55, P<0.001 ; \mathrm{JD} \times$ time, $\left.F_{20.770}=0.93, P=0.469\right) .{ }^{*} P<0.05$. 


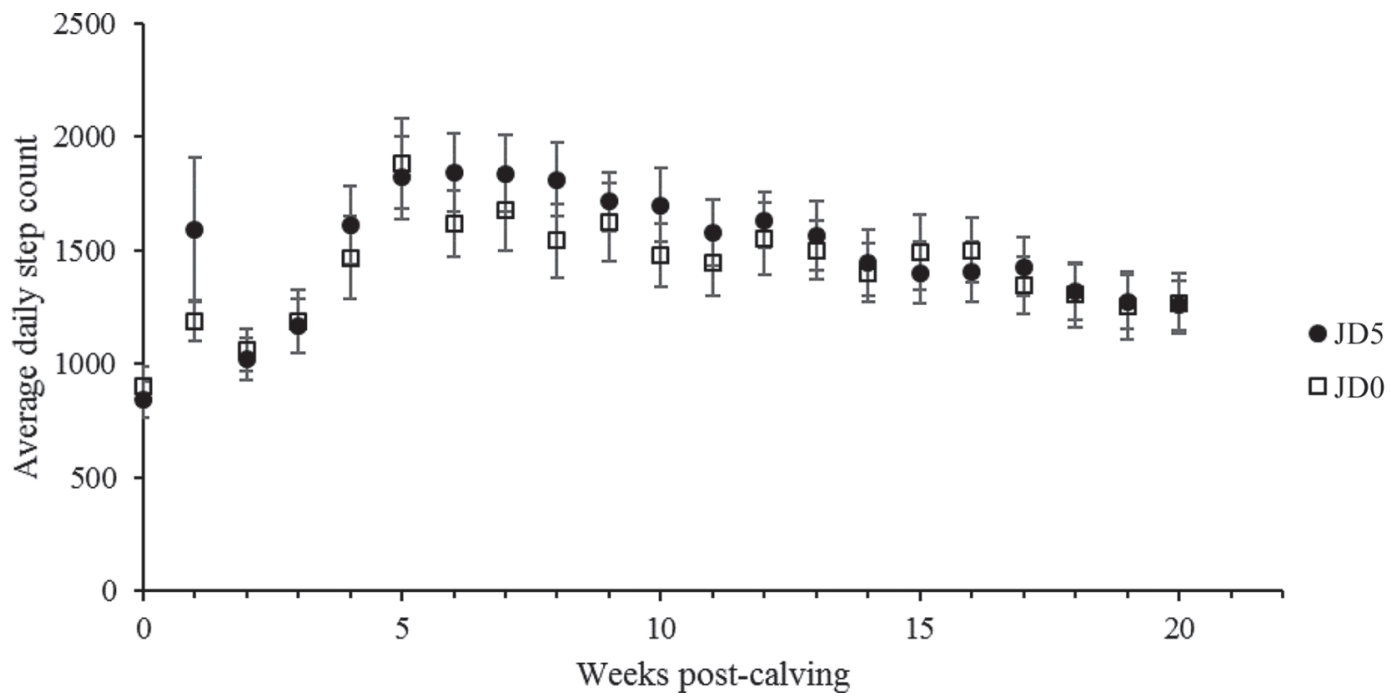

Figure 4. Mean $( \pm \mathrm{SEM})$ daily number of steps of Johne's disease (JD)-positive [JD5; $\mathrm{n}=21$ (repeat ELISA positive)] and JD-negative [JD0; $\mathrm{n}=21$ (repeat ELISA negative)] Holstein Friesian dairy cows from calving to wk 20 of lactation $\left(\mathrm{JD}, F_{1,40}=0.18, P=0.676 ;\right.$ time, $F_{20,772}=$ $10.72, P<0.001 ; \mathrm{JD} \times$ time, $\left.F_{20.772}=0.65, P=0.656\right)$.

We speculate that during peak lactation when lying behavior was different between the JD5 and JD0 cows, the JD5 cows may have been standing at the feed fence, eating. This is supported by the fact there was no difference in step count between JD5 and JD0 cows from calving to wk 20 of lactation. Unfortunately, feeding behavior and feed intake were not recorded during our study and therefore further investigation is required to establish how JD5 cows spent their time when lying was reduced. When describing the clinical stages of $\mathrm{JD}$, the mention of a loss in body condition is often followed by a statement explaining that it is despite a good or normal appetite (Garcia and Shalloo, 2015; Fecteau, 2018). However, to our knowledge no study has investigated the feeding behavior or feed intake of cows with JD at the subclinical or clinical stage of the disease; therefore, this warrants further investigation. Johne's disease causes inflammation and malfunction of the intestinal tract, and intestinal lesions caused by JD can reduce the absorption of nutrients and proteins (Caldow et al., 2001; Garcia and Shalloo, 2015), which could explain why cows with JD may have an increase

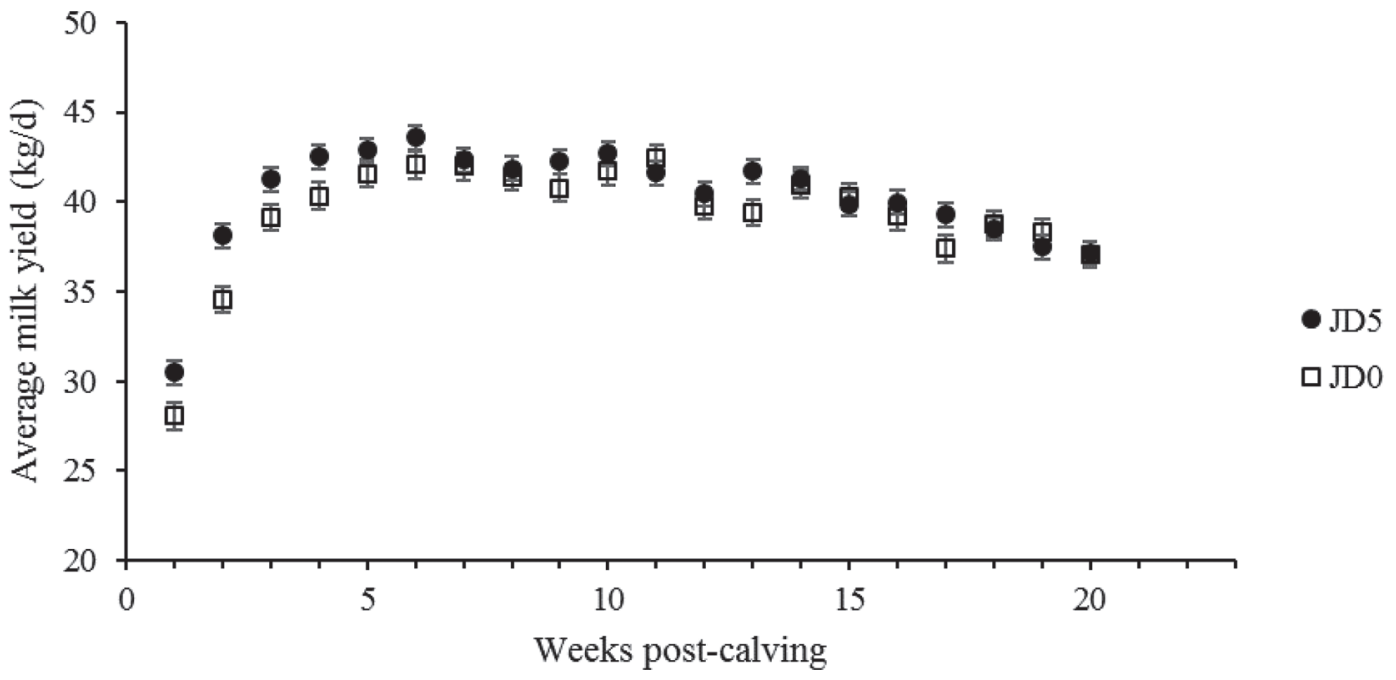

Figure 5. Mean $( \pm$ SEM) daily milk yield $(\mathrm{kg} / \mathrm{d})$ of Johne's disease $(\mathrm{JD})$-positive [JD5; $\mathrm{n}=21$ (repeat ELISA positive)] and JD-negative $\left[\mathrm{JD} 0 ; \mathrm{n}=21\right.$ (repeat ELISA negative) Holstein Friesian dairy cows from calving to wk 20 of lactation $\left(\mathrm{JD}, F_{1,40}=0.80, P=0.377 ;\right.$ time, $F_{19,709}$ $=18.93, P<0.001 ; \mathrm{JD} \times$ time $\left., F_{19,709}=0.64, P=0.543\right)$. 


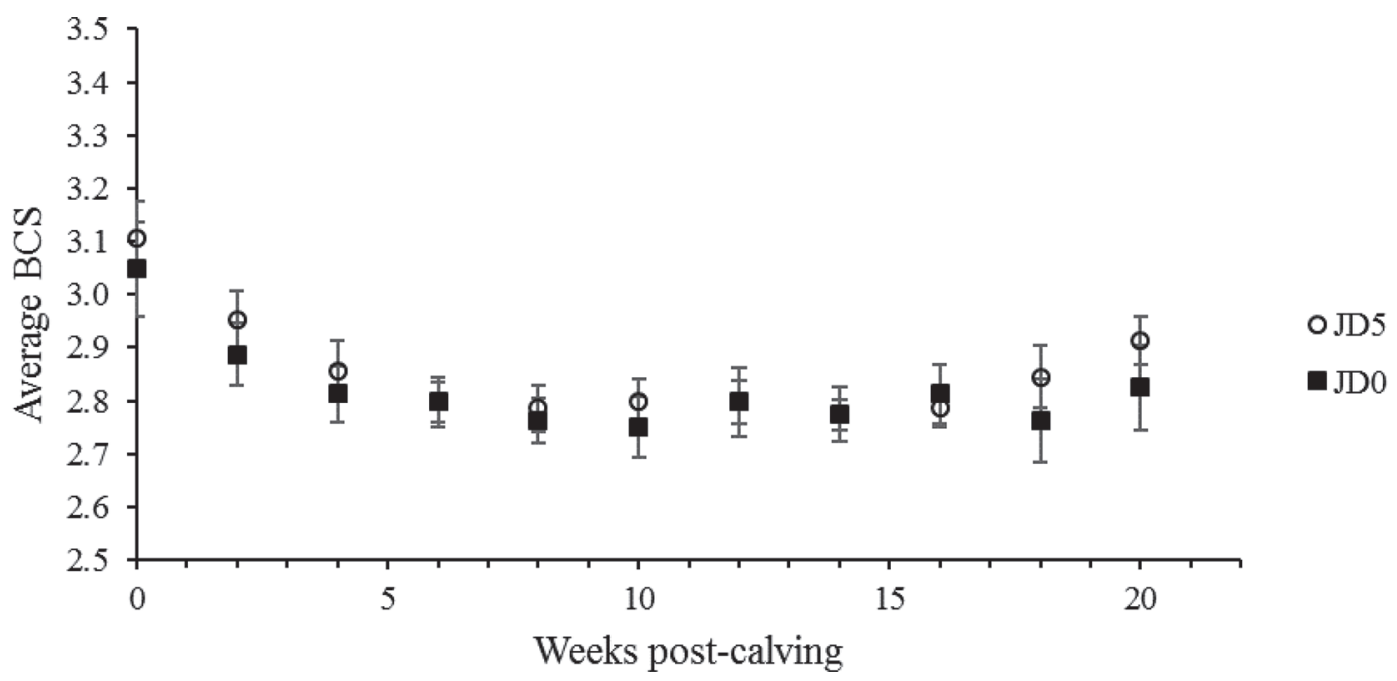

Figure 6. Mean ( \pm SEM) BCS of Johne's disease (JD)-positive [JD5; $\mathrm{n}=21$ (repeat ELISA positive)] and JD-negative [JD0; $\mathrm{n}=21$ (repeat ELISA negative)] Holstein Friesian dairy cows from calving to wk 20 of lactation (JD, $F_{1,40}=0.36, P=0.553 ;$ time, $F_{10,393}=13.40, P<0.001$; $\mathrm{JD} \times$ time, $\left.F_{10,393}=0.68, P=0.638\right)$.

in feed intake, particularly around peak lactation when nutrient demand is at the greatest level.

Numerous studies have reported a reduction in milk production as a result of JD (Nielsen et al., 2009; McAloon et al., 2016). A study by Martins et al. (2018), investigating milk production across 5 lactations, found that MAP status affected milk yield, with an average loss of $1,284.8 \mathrm{~kg}$ of milk from JD-positive (at least 1 positive ELISA test result) compared with JD-negative cows (all test results were negative). However, JD- positive cows had, on average, higher milk production during their first lactation than JD-negative cows and it was from the third lactation onward that the losses were detectable (Martins et al., 2018), although the authors did not report whether the JD-positive cows were showing any clinical signs of the disease. In the current study, we did not detect any difference in milk yield between the JD5 and JD0 cows. Of the cows in the present study, $48 \%$ (10 of 21 cows) of the JD5 cows were in lactation 2 and a further $24 \%$ ( 5 of 21 cows)

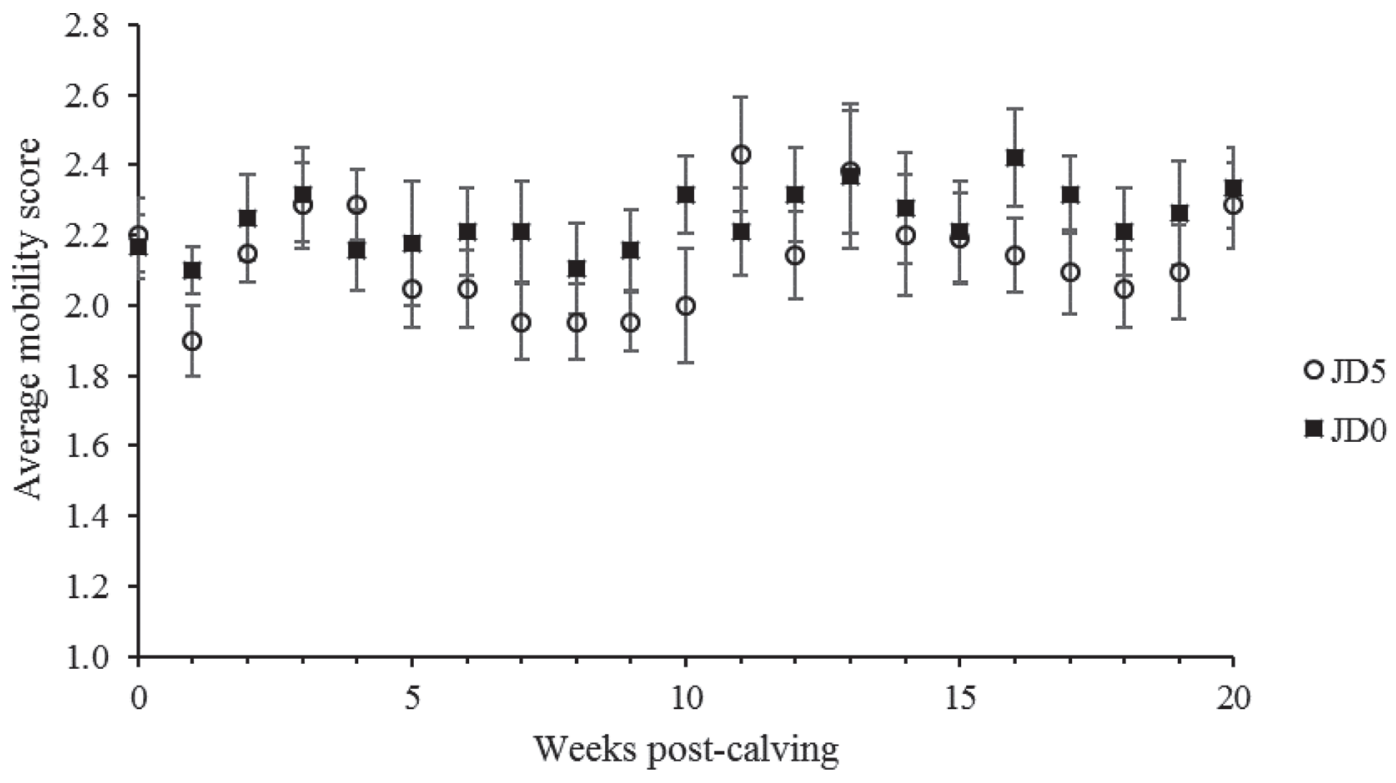

Figure 7. Mean $( \pm$ SEM) mobility score of Johne's disease $(\mathrm{JD})$-positive $[\mathrm{JD} 5 ; \mathrm{n}=21$ (repeat ELISA positive) and JD-negative $[$ JD0; $\mathrm{n}=$ 21 (repeat ELISA negative)] Holstein Friesian dairy cows from calving to wk 20 of lactation $\left(\mathrm{JD}, F_{1,39}=1.67, P=0.205 ;\right.$ time, $F_{20,746}=1.90, P$ $=0.055 ; \mathrm{JD} \times$ time, $\left.F_{20.746}=0.79, P=0.623\right)$. 
were in lactation 3 ; therefore, milk yield losses associated with JD may not have been detectable due to age and lactation number. Stage of infection could also affect milk yield losses associated with JD (Nielsen et al., 2009), as not all animals will have long-term production losses (Smith et al., 2016). In addition, compared with some studies that have used data from several thousands of cows, the current study is relatively small, which may explain why a difference in milk yield was not detected between the JD5 and JD0 cows. Furthermore, we compared the current milk yields of the cows, which may be different to the potential yield of the JD5 cows. We did find that milk yield in both JD5 and JD0 cows changed over time, which we would expect due to the standard lactation curve of Holstein Friesian dairy cattle (Silvestre et al., 2009).

Weight loss and a reduction in BCS is associated with the clinical signs of JD (McKenna et al., 2006). The finding of no differences in BCS in the current study suggests that JD5 cows were not yet showing clinical signs of the disease. Similarly, McKenna et al. (2004) reported no association between BCS and JD infection status, with over $70 \%$ of JD-positive cows having a BCS of $\geq 2.75$. However, the authors did not provide detail on whether the JD-positive cows were in the subclinical or clinical stage of the disease. Average BCS for JD-positive cows, reported by McKenna et al. (2004), was 2.9, which is similar to the average BCS of the JD5 cows in the current study. We did find a difference in BCS over time, which would be expected postcalving (Roche et al., 2009).

Cows infected with JD are more prone to other diseases such as lameness (Garcia and Shalloo, 2015). Lameness was reported as the most common clinical disease in JD fecal culture positive cows (Raizman et al., 2007), yet in the present study no difference in mobility score was found between JD5 and JD0 cows. Overall, very little literature is available on the association between JD and lameness.

No accepted single gold-standard test for JD in live animals is available, and this is due to variation in the sensitivity and specificity of diagnostic tests for the various stages of the infection (Nielsen and Toft, 2008). This makes controlling JD very challenging. A review of accuracies of various diagnostic tests was carried out by Nielsen and Toft (2008), which showed sensitivity of 21 to $61 \%$ for milk ELISA, 7 to $94 \%$ for serum ELISA, and 23 to $74 \%$ for fecal culture. With such variation, use of a combination of tests or more frequent testing may be necessary to increase the detection rate of JDpositive cows and possibly for earlier diagnosis too, and thus improve control of the disease. However, testing for JD can be expensive and potentially time consuming. The current study has demonstrated differences in lying behavior between JD0 and JD5 cows. Although these results may have been influenced by potentially confounding factors such as mastitis or ketosis, we believe any effect will have been negligible given the low incidence of these other diseases compared with the major differences in JD status between the 2 groups of cows. As our understanding of the many factors affecting cow lying behavior improves, there is the potential in the future for using on-farm activity and behavior monitoring to help in the diagnosis of a range of health conditions that may include JD. More research is required to establish whether cows with JD spend more time eating during periods of reduced lying, and whether feed intake is increased, as these data may further assist in the early diagnosis of cows with JD.

\section{CONCLUSIONS}

Around peak lactation, JD5 cows reduced their lying time and lying bout frequency, and lying bouts were longer in duration compared with JD0 cows. The results show that activity data from leg-mounted accelerometers have the potential to help identify cows with JD, although more research is required.

\section{ACKNOWLEDGMENTS}

The authors thank Carrie Gauld for scoring the cows throughout the study, and Kyra Hamilton and Thijs Almekinders (all from Harper Adams University, Shropshire, United Kingdom) for assistance in formatting milk yields. This research was funded by Innovate UK (Swindon, United Kingdom).

\section{REFERENCES}

Bartlett, B., and H. L. Pearse. 2012. Integrating milk recording data and disease test results to provide a system for the management of paratuberculosis in UK dairy herds. In Proc. ICAR., May 28-June 1, 2012, Cork, Ireland. Accessed Jul. 1, 2019. https://www.icar .org/wp-content/uploads/2015/09/Bartlett.pdf.

Blackie, N., J. Amory, E. Bleach, and J. Scaife. 2011. The effect of lameness on lying behaviour of zero grazed Holstein dairy cattle. Appl. Anim. Behav. Sci. 134:85-91.

Borchers, M. R., Y. M. Chang, I. C. Tsai, B. A. Wadsworth, and J. M. Bewley. 2016. A validation of technologies monitoring dairy cow feeding, ruminating, and lying behaviors. J. Dairy Sci. 99:7458 7466.

Caldow, G., D. C. Henderson, and C. J. Low. 2001. Epidemiology. Pages 28-37 in Assessment of surveillance and control of Johne's disease in farm animals in GB. G. Caldow, A. Greig, G. J. Gunn, R. Humphry, C. J. Low, S. W. Ashworth, G. M. Jones, A. W. Stott, M. V. Cranwell, J. M. Sharp, K. Stevenson, and D. C. Henderson, ed. Veterinary Science Division, Scottish Agricultural College.

Cocito, C., P. Gilot, M. Coene, M. De Kesel, P. Poupart, and P. Vannuffel. 1994. Paratuberculosis. Clin. Microbiol. Rev. 7:328-345.

Elanco Animal Health. 1996. Body condition scoring. Bulletin AI 8478, Rev. 9/96. Elanco Animal Health, Indianapolis, IN.

Fecteau, M.-E. 2018. Paratuberculosis in cattle. Vet. Clin. North Am. Food Anim. Pract. 34:209-222. 
Flower, F. C., and D. M. Weary. 2006. Effect of hoof pathologies on subjective assessments of dairy cow gait. J. Dairy Sci. 89:139-146.

Fogsgaard, K. K., T. W. Bennedsgaard, and M. S. Herskin. 2015. Behavioral changes in freestall-housed dairy cows with naturally occurring clinical mastitis. J. Dairy Sci. 98:1730-1738.

Garcia, A. B., and L. Shalloo. 2015. Invited review: The economic impact and control of paratuberculosis in cattle. J. Dairy Sci. 98:5019-5039.

Henderson, D. C., G. Caldow, and C. J. Low. 2001. Paratuberculosis in cattle: pathology and clinical disease (chapter 3). Pages 15-19 in Assessment of surveillance and control of Johne's disease in farm animals in GB. G. Caldow, A. Greig, G. J. Gunn, R. Humphry, C. J. Low, S. W. Ashworth, G M. Jones, A. W. Stott, M. V. Cranwell, J. M. Sharp, K. Stevenson, and D. C. Henderson, ed. Veterinary Science Division, Scottish Agricultural College.

Itle, A. J., J. M. Huzzey, D. M. Weary, and M. A. G. von Keyserlingk. 2015. Clinical ketosis and standing behavior in transition cows. J. Dairy Sci. 98:128-134.

Ito, K., M. A. G. von Keyserlingk, S. J. LeBlanc, and D. M. Weary. 2010. Lying behavior as an indicator of lameness in dairy cows. J. Dairy Sci. 93:3553-3560.

Martins, E. G., P. Oliveira, B. M. Oliveira, D. Mendonça, and J. Niza-Ribeiro. 2018. Association of paratuberculosis sero-status with milk production and somatic cell counts across 5 lactations, using multilevel mixed models, in dairy cows. J. Dairy Sci. 101:76387649

Mattachini, G., A. Antler, E. Riva, A. Arbel, and G. Provolo. 2013. Automated measurement of lying behavior for monitoring the comfort and welfare of lactating dairy cows. Livest. Sci. 158:145-150.

McAloon, C. G., P. Whyte, S. J. More, M. J. Green, L. O'Grady, A. Garcia, and M. L. Doherty. 2016. The effect of paratuberculosis on milk yield - A systematic review and meta-analysis. J. Dairy Sci. 99:1449-1460.

McKenna, S. L., G. P. Keefe, A. Tiwari, J. VanLeeuwen, and H. W. Barkema. 2006. Johne's disease in Canada part II: Disease impacts, risk factors, and control programs for dairy producers. Can. Vet. J. 47:1089-1099.

McKenna, S. L. B., G. P. Keefe, H. W. Barkema, J. McClure, J. A VanLeeuwen, P. Hanna, and D. C. Sockett. 2004. Cow-level prevalence of paratuberculosis in culled dairy cows in Atlantic Canada and Maine. J. Dairy Sci. 87:3770-3777.

Neave, H. W., J. Lomb, D. M. Weary, S. J. LeBlanc, J. M. Huzzey, and M. A. G. von Keyserlingk. 2018. Behavioral changes before metritis diagnosis in dairy cows. J. Dairy Sci. 101:4388-4399.

Nielsen, S. S., M. A. Krogh, and C. Enevoldsen. 2009. Time to the occurrence of a decline in milk production in cows with various paratuberculosis antibody profiles. J. Dairy Sci. 92:149-155.

Nielsen, S. S., and N. Toft. 2008. Ante mortem diagnosis of paratuberculosis: A review of accuracies of ELISA, interferon-g assay and faecal culture techniques. Vet. Microbiol. 129:217-235.

Nielsen, S. S., and N. Toft. 2009. A review of prevalences of paratuberculosis in farmed animals in Europe. Prev. Vet. Med. 88:1-14.

NMR (National Milk Records). Undated. Testing for Johne's Disease. Accessed Jul. 3, 2019. https://www.nmr.co.uk/uploads/files/files/ testingforjohnes.pdf.
Ott, S. L., S. J. Wells, and B. A. Wagner. 1999. Herd-level economic losses associated with Johne's disease on US dairy operations. Prev. Vet. Med. 40:179-192.

Pritchard, T. C., M. P. Coffey, K. S. Bond, M. R. Hutchings, and E. Wall. 2017. Phenotypic effects of subclinical paratuberculosis (Johne's disease) in dairy cattle. J. Dairy Sci. 100:679-690.

Raizman, E. A., J. Fetrow, S. J. Wells, S. M. Godden, M. J. Oakes, and G. Vazquez. 2007. The association between Mycobacterium avium ssp. paratuberculosis fecal shedding or clinical Johne's disease and lactation performance on two Minnesota, USA dairy farms. Prev. Vet. Med. 78:179-195.

Roche, J. R., N. C. Friggens, J. K. Kay, M. W. Fisher, K. J. Stafford, and D. P. Berry. 2009. Invited review: Body condition score and its association with dairy cow productivity, health, and welfare. J. Dairy Sci. 92:5769-5801.

Rossi, G., Y. T. Grohn, Y. H. Schukken, and R. L. Smith. 2017. The effect of Mycobacterium avium ssp. paratuberculosis infection on clinical mastitis occurrence in dairy cows. J. Dairy Sci. 100:74467454

Silvestre, A. M., A. M. Martins, V. A. Santos, M. M. Ginja, and J. A. Colaço. 2009. Lactation curves for milk, fat and protein in dairy cows: A full approach. Livest. Sci. 122:308-313.

Smith, R. L., Y. T. Gröhn, A. K. Pradhan, R. H. Whitlock, J. S. Van Kessel, J. M. Smith, D. R. Wolfgang, and Y. H. Schukken. 2016. The effects of progressing and nonprogressing Mycobacterium avium ssp. paratuberculosis infection on milk production in dairy cows. J. Dairy Sci. 99:1383-1390.

Stabel, J. R. 1998. Johne's disease: A hidden threat. J. Dairy Sci. $81: 283-288$.

USDA. 2008. Johne's disease on US dairies, 1991-2007. United States Department of Agriculture (USDA)- Animal and Plant Health Inspection Service (APHIS)-Veterinary Services (VS)-Center for Epidemiology and Animal Health (CEAH)-National Animal Health Monitoring System (NAHMS). Fort Collins, CO. Accessed Jun. 14, 2018. https://www.aphis.usda.gov/animal_health/nahms/ dairy/downloads/dairy07/Dairy07_is_Johnes.pdf.

Weber, M. F., J. Kogut, J. de Bree, G. van Schaika, and M. Nielenc. 2010. Age at which dairy cattle become Mycobacterium avium ssp. paratuberculosis faecal culture positive. Prev. Vet. Med. 97:29-36.

Woodbine, K. A., Y. H. Schukken, L. E. Green, A. Ramirez-Villaescusa, S. Mason, S. J. Moore, C. Bilbao, N. Swann, and G. F. Medley. 2009. Seroprevalence and epidemiological characteristics of Mycobacterium avium ssp. paratuberculosis on 114 cattle farms in south west England. Prev. Vet. Med. 89:102-109.

\section{ORCIDS}

Gemma L. Charlton ํㅏ https://orcid.org/0000-0002-8395-3821 Emma C. L. Bleach ๑ https://orcid.org/0000-0002-2277-255X 